ZOOLOGIA 28 (6): 803-811, December, 2011

doi: $10.1590 /$ S1984-46702011000600014

\title{
New species of Cyamops (Diptera: Opomyzoidea: Periscelididae) from the old and new world tropics
}

\author{
Alessandra Rung ${ }^{1} \&$ Rosaly Ale-Rocha ${ }^{2}$ \\ 1 Plant Pest Diagnostics Branch, California Department of Food and Agriculture. Sacramento, CA 95832, USA. \\ E-mail: arung@cdfa.ca.gov \\ 2 Instituto Nacional de Pesquisas da Amazônia. Caixa Postal 478, 69011-970 Manaus, AM, Brazil. \\ E-mail: alerocha@inpa.gov.br
}

\begin{abstract}
Two new species of Cyamops Melander are described, one from the Afrotropical and one from the Neotropical Region. The newly described species are (type locality in parenthesis): Cyamops mathisi sp. nov. (Province Fianarantsoa, Madagascar) and Cyamops manauensis sp. nov. (state of Amazonas, Brazil). Both species can be separated from congeners based on characters of the male genitalia, particularly the shape of the surstyli. A new country, the Ivory Coast, is added to the distribution records of Cyamops nigeriensis, previously known only from Nigeria and Namibia. Updated keys to the Afrotropical and Neotropical species of the genus are also given.
\end{abstract}

KEY WORDS. Afrotropical Region; Brazil; Madagascar; Neotropical Region; Stenomicrinae.

Cyamops Melander, 1913 includes 32 valid species: two from the Afrotropical Region, 14 from the Australasian/ Oceanian Region, three from the Nearctic Region, seven from the Neotropical Region, five from the Oriental Region, and one from the Palearctic Region (Mathis \& Rung 2011, Mathis \& Sueyoshi 2011). Despite the fact that the taxonomy of the genus has been well-documented in recent years, very little is known about the biology of the included species, and immatures have never been found. Adults have been collected near streams, on rocks in streams, near waterfalls, in marshy habitats (often on broad-leaved plants), and beside pools in almost dry riverbeds (Кноо 1985).

Baptista \& Mathis (1994) last reviewed the Neotropical fauna of Cyamops, and a few new species were later added by the same authors $(1996,2000)$. The two Afrotropical species were described in a single contribution (BAPTISTA \& MATHIS 2000). The genus was recently catalogued and its classification was briefly discussed by MATHIs \& Rung (2011).

In this paper we describe two new species, one from Madagascar and one from northern Brazil. We also provide locality data on the discovery of C. nigeriensis Baptista \& Mathis, 2000 in the Ivory Coast. The Brazilian specimens were collected as part of an insect survey in the Amazon using Malaise and "Suspensa" traps (RAFAel \& Gorayeb 1982). In order to facilitate identification of the new species, we have updated the keys to the Afrotropical and New World species (modified from BAPTISTA $\&$ MathIs 2000). We also present illustrations of the external morphology and diagnostic structures of the male terminalia of the new species. A diagnosis of Periscelididae, a world key to the included subfamilies, genera and subgenera, as well as a discussion of the taxonomic placement of Cyamops have been recently published (MATHIS \& Rung 2011) and will not be replicated here. The most recent description of the genus can be found in Mathis \& Sueyoshi (2011).

\section{MATERIAL AND METHODS}

The descriptive terminology, with the exceptions noted in BAPTISTA \& Mathis $(1994,2000)$, follows the Manual of Nearctic Diptera (McAlpine 1981). For some structures of the male terminalia, we follow the terminology adopted by other workers in Periscelididae (Baptista \& Mathis 1994, 2000, Sueyoshi \& Mathis 2004, Mathis \& Sueyoshi 2011). The format for the species' descriptions adheres to BAptista \& Mathis $(1994,2000)$. Species' descriptions are composite, including information on the holotype and other conspecific specimens. All species exhibit sexual dimorphism to some degree, although not always in the same characters. To account for this variation in the descriptions, we describe the male first, followed by a section on differences in the female. Three wing vein ratios used in the descriptions of the new species are based on the largest and smallest specimens and are defined as: (1) wing ratio: straight line distance between wing base and apex/greatest straight line distance from anterior margin to posterior margin; (2) costal vein ratio I: the straight line distance between the apices of $R_{1}$ and $R_{2+3}$ (costal section II)/distance between the apices of $R_{2+3}$ and $\mathrm{R}_{4+5}$ (costal section III); (3) costal vein ratio II: straight line distance between the apices of $\mathrm{R}_{2+3}$ and $\mathrm{R}_{4+5}$ (costal section IV)/ 
distance between the apices of $\mathrm{R}_{4+5}$ and $\mathrm{M}$ (costal section III). Because specimens are small, study and illustration of the male and female terminalia required use of a compound microscope. Photographs were taken with a Nikon Coolpix Ds-Fi1 digital camera using a Nikon SMZ1500 stereomicroscope. In order to produce final images with most structures in focus, we took several photograph layers of each body part and subsequently assembled them with Combine ZM 2008. The photographs were enhanced, formatted and arranged in Adobe Photoshop 7тм

The Brazilian specimens examined as part of this study are deposited in the Instituto Nacional de Pesquisas da Amazônia (INPA), Manaus, and Coleção Zoológica da Universidade Estadual do Maranhão (CZMA), Caxias. Specimens from the Afrotropics are at the California Academy of Sciences (CAS), San Francisco, and the California State Collection of Arthropods (CSCA), Sacramento.

\section{TAXONOMY}

\section{Cyamops Melander, 1913}

Cyamops Melander, 1913: 291. Type species: C. nebulosus Melander, by original designation. Sturtevant 1954: 557-559 [revision]; Hennig 1958: 633 [generic characters, relationships], 1969: 610-613 [discussion]; Sabrosky 1958: 169-171 [revision], 1965: 820 [Nearctic catalog]; Khoo 1985: 527536 [revision, Australian species]; Khoo \& Sabrosky 1989: 551 [Australasian/Oceanian catalog]; Baptista \& Mathis 1994: 1-25 [revision, New World species], 2000: $481-506$ [review]; Poole \& Gentili 1996: 65 [checklist, Nearctic]; Grimaldi 2009: 23-27, 38 [key] [fauna of Fiji]; Mathis \& Rung 2011: 359-363 [World catalog].

Diagnosis. Cyamops can be easily recognized and separated from other genera of Periscelididae by the following combination of characters: Frons lacking interfrontal setae; 2 fronto-orbital setae, 1 proclinate and 1 reclinate; medial vertical seta absent; face in profile shallowly and vertically arched, lacking a flattened dorsal area; eyes microsetulose (sometimes sparsely). Katepisternum bearing 1 prominent seta; supra-alar seta well developed. Hind femur lacking anterodorsal, preapical seta. Crossvein bm-cu well developed, cell bm distinct from cell dm; vein CuA2 well developed; cell cup present. Male postabdomen and terminalia strongly asymmetrical, especially surstyli; ejaculatory apodeme large. Female abdomen with segment 6 forming a complete ring.

\section{Afrotropical species}

With the inclusion of the new species described below, a total of three species of Cyamops are known in the Afrotropical Region, two in Madagascar and one in Nigeria, Namibia and the Ivory Coast (new record, see below). All known Afrotropical species have two spermathecae, a character state common to all Old World species, and lack setae on the posterior dorsal margin of the anepisternum.

\section{Key to Afrotropical species of Cyamops Melander}

1. Only apical scutellar seta present; dorsocentral setae $0+2$; hind femur mostly yellow, infuscate apically; wing mostly brown with 2 conspicuous white spots along anterior margin, and 2 white spots along posterior margin (BAPTISTA \& Mathis 2000: 505, fig. 33) (Ivory Coast, Nigeria, Namibia). C. nigeriensis Baptista \& Mathis

$1^{\prime}$. Apical and basal scutellar setae present (Figs 6 and 8); dorsocentral seta $0+1$ (Fig. 6); hind femur brown on apical $1 / 2-3 / 4$; wing hyaline or only lightly infuscate (Madagascar)...2

2. Right surstylus in ventral view with apical margin deeply concave in middle, claw-shaped; left surstylus in ventral view irregular, tapered apically, triangular apex aligned with surstylar axis (BAPTISTA \& MATHIs 2000: 491, fig. 11) C. freidbergi Baptista \& Mathis

2 '. Right surstylus in ventral view roughly triangular with round corners; left surstylus in ventral view with triangular apex expanded toward the left side of the abdomen (Fig. 9) .... ..C. mathisi sp. nov.

\section{Cyamops mathisi sp. nov.}

Figs 1-10

Description. Male (three specimens measured): Adult length 1.9-2.1 mm; wing length 1.7-2 mm; wing width 0.6$0.75 \mathrm{~mm}$. Head: Ocellar tubercle mostly polished, shiny spot on vertex reaching $2 / 3$ distance to eye margin; frons subshiny microtomentose, velvet at deepest portion, parafacial margins densely microtomentose, silver up to just underneath insertion of fronto-orbital setae; antenna mostly yellow, slightly infuscate at dorsal margin of scape; face constricted medially by anteroventral margin of eyes, expanded into a ventral triangular region below level of pseudovibrissae and bearing a vertical, midfacial, yellow carina, facial triangle mostly yellow; gena yellow, when viewed anteriorly conspicuously silvery white microtomentose; palpus and labellum mostly pale yellow; face in profile shallowly and vertically arched, not angulate; eye sparsely microsetulose. Chaetotaxy: Medial fronto-orbital setae slightly divergent; arista with about 8-9: 3 rays, 4-5 basal rays clearly bifurcate; peristomal setae 7-8. Thorax: Mostly brown. Postpronotum subshiny microtomentose; halter mostly white, infuscate at base; mesonotum slightly longer than wide; scutellum trapezoidal, disc flattened. Chaetotaxy: Dorsocentral setae $0+1$, subequal in length to the $1^{\text {st }}$ scutellar seta; few setulae between dorsocentral and acrostichal rows in most specimens; setulae of mesonotum at most $1 / 3$ length of dorsocentral seta; scutellar setae 2 pairs, basal pair about $2 / 3$ length of apical. Legs: Mostly yellow; hind femur brown on apical $1 / 2-3 / 4$; apical and sometimes subapical tarsomere of each leg brown; spine-like setulae on fore femur 5. Wing: Mostly hyaline, central portion very slightly infuscate with brown; costal vein ratio I: 0.9-1; costal vein ratio II: 3.3-3.7; wing ratio 2.6-3.1. Abdomen (Figs 9 and 10): Coloration as described for the thorax, without pol- 

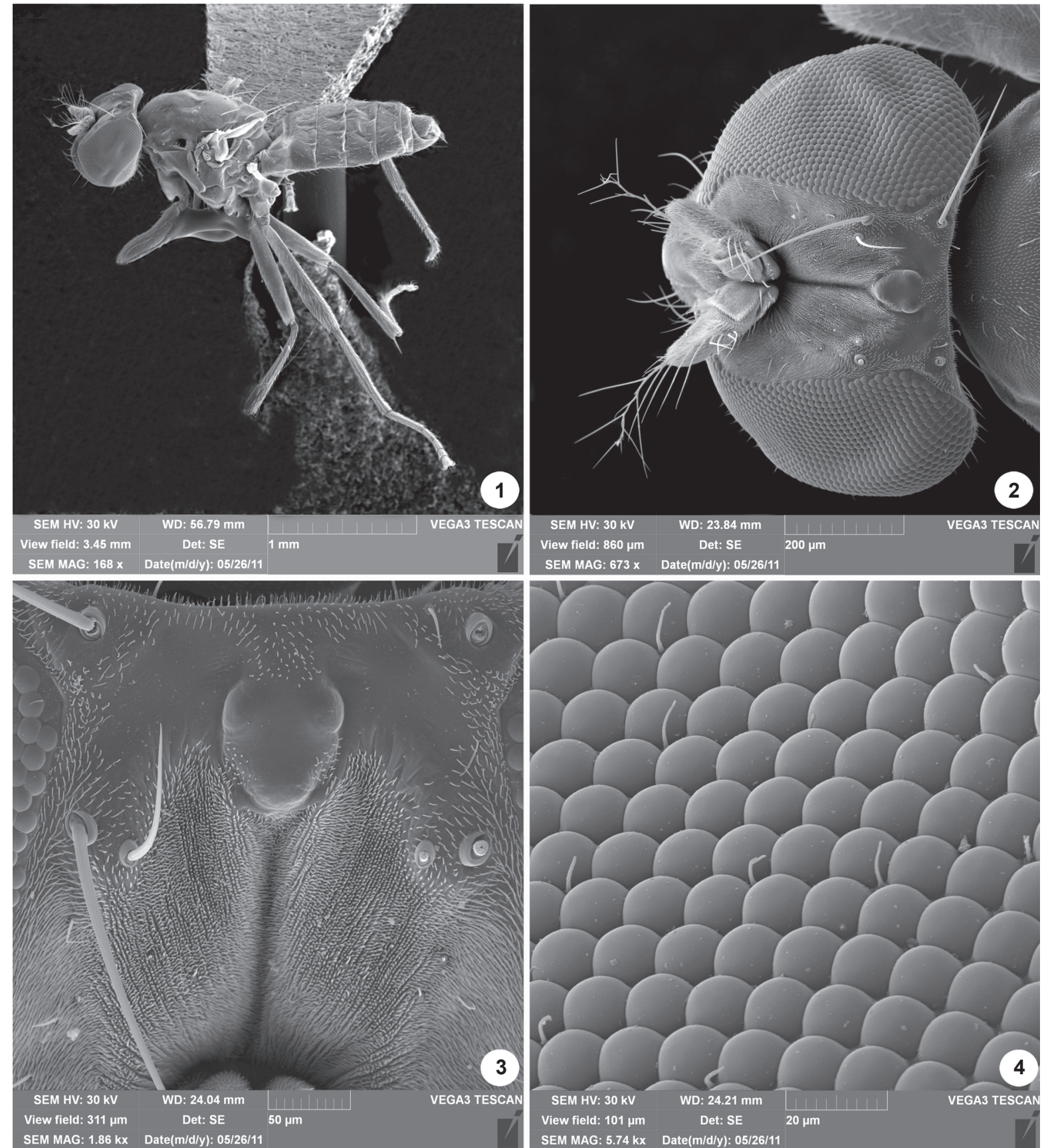

Figures 1-4. Scanning electron micrographs of Cyamops mathisi sp. nov. (female, Madagascar: Province Fianarantsoa): (1) habitus, lateral view; (2) head, dorsal view; (3) frons, frontal view; (4) eye facets and interfacetal setulae of left eye, lateral view.

ished segments; $6^{\text {th }}$ and $7^{\text {th }}$ tergites large, subequal in length; posterior process of $6^{\text {th }}$ and $7^{\text {th }}$ sternites as in Fig. 9. Male terminalia as follows (Figs 9 and 10): Left surstylus narrow, in ventral view with base expanded and apex pointing to the left side; right surstylus slightly shorter but considerably wider than left, in ventral view subtriangular with round corners; hypandrium asymmetrical, gonopods not clearly differentiated; ejaculatory apodeme with two main axes making a right angle with one another, longest axis triangular in dorsal view, as long as right surstylus, shorter axis mostly parallel-sided with subapi- 

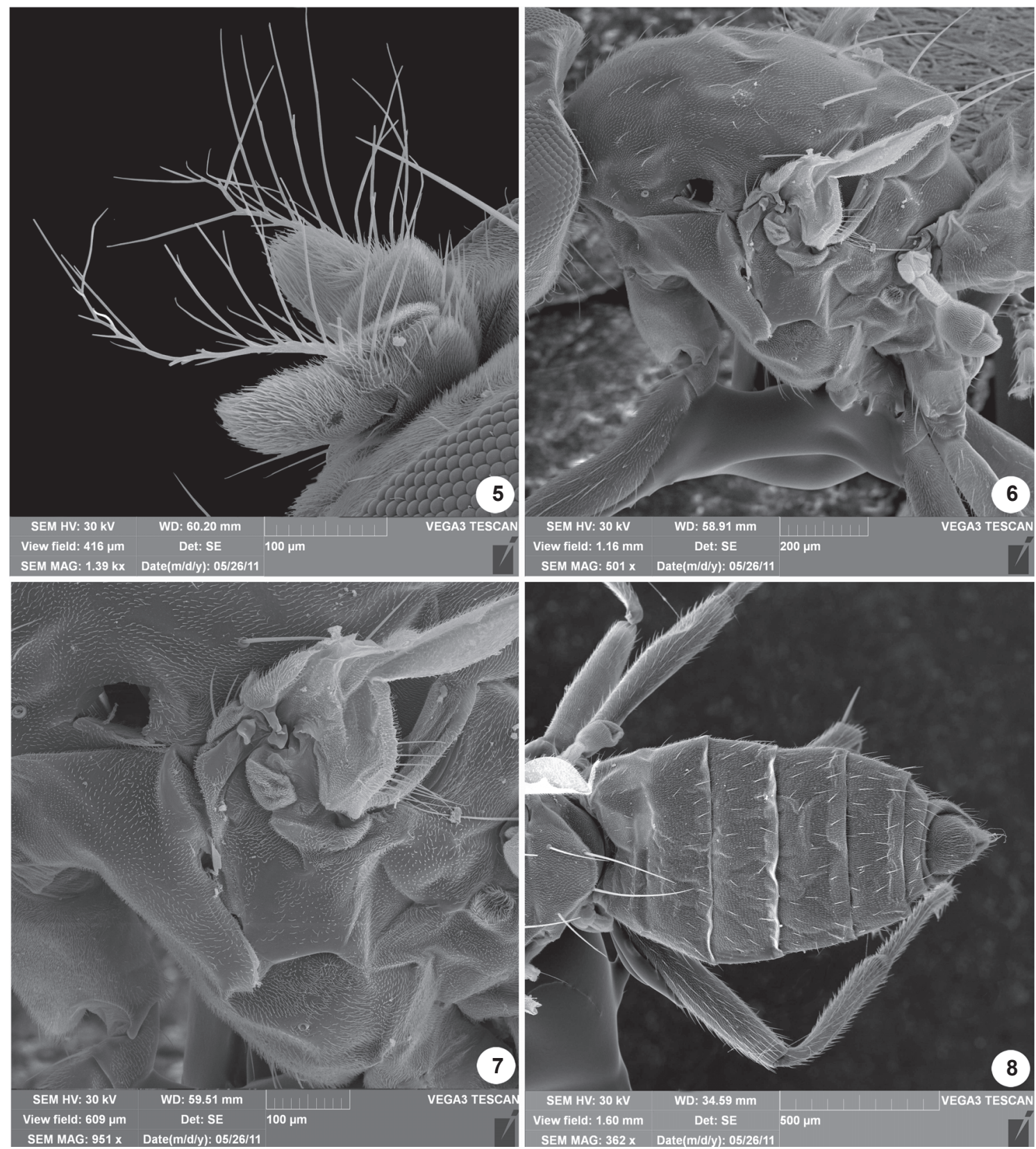

Figures 5-8. Scanning electron micrographs of Cyamops mathisi sp. nov. (female, Madagascar: Province Fianarantsoa): (5) close up of antennae, lateral view; (6) thorax, lateral view; (7) pleural region of thorax, lateral view; (8) abdomen, dorsal view.

cal notch; postero-ventral portion of aedeagal apodeme fused with hypandrium.

Female (3 specimens measured): Adult length 2.1-2.3 mm (Fig. 1); wing length 2.1-2.3 mm; wing width $0.8 \mathrm{~mm}$. Head (Figs 2-5): Ocellar tubercle polished and shiny spot on vertex more extensive; arista with about 9-10: 3 rays, 5-6 basal rays clearly bifurcate; face mostly light brown, not constricted medially by the eyes, with a more elevated, parallel, central region (a broad carina); facial carina mostly subshiny except for densely microtomentose basal 1/4; gena and lateral portions of face below level of pseudovibrissa strongly microtomentose; face in profile angulate, sloped anteroventrally from base of antenna to vibrissal angle, thereafter slightly receded to oral margin; arista with 1314 dorsal rays. Thorax (Figs 6 and 7): Wing somewhat infuscate 


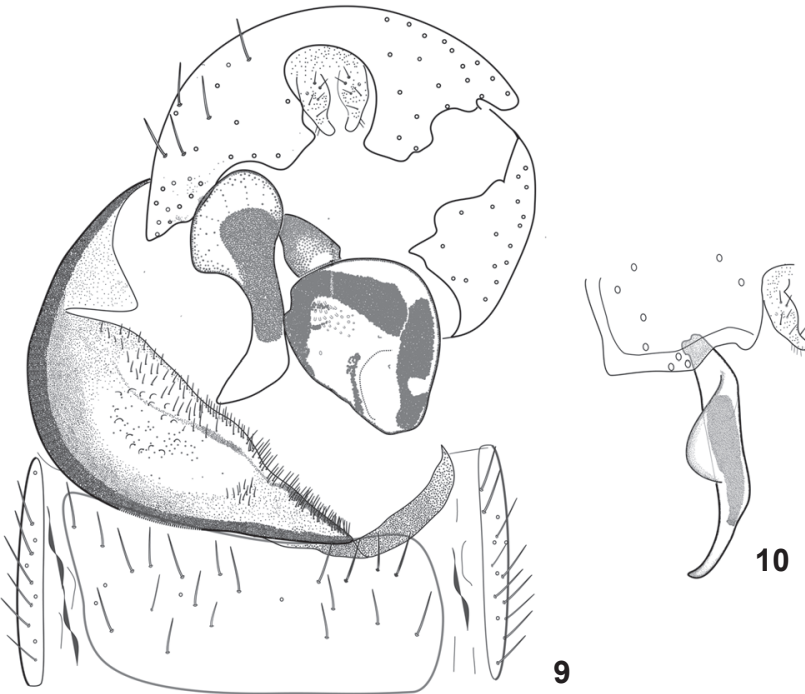

Figures 9-10. Illustrations of the male terminalia of Cyamops mathisi sp. nov., paratype: (9) abdominal segments 5-7 and epandrium, ventral view; (10) left surstylus, lateral view.

in some specimens, with the following areas completely hyaline: cells sc and $\mathrm{r}_{1}$, dorsal $2 / 3$ of cell $\mathrm{r}_{2+3}$, posterior portion of cell $\mathrm{m}$ and somewhat cell cua ${ }_{1}$. Abdomen (Fig. 8): Demarcation between tergites 7 and 8 sharp dorsally; sternite 8 fused to $7^{\text {th }} ; 2$ spermathecae present, oblong, both the same size; apical portion of spermathecal ducts with a very thin area bearing sclerotization.

Type material: The holotype male is labeled "MADAGASCAR: Province Fianarantsoa, near Isalo National Park, in dry wash east of interpretive Center [,] 28 March- 9 April 2003 [,] $22^{\circ} 37.50^{\prime} \mathrm{S}, 45^{\circ} 21.49^{\prime} \mathrm{E}$ [,] coll: M. Irwin, R. Harin'Hala [,] California Academy of Sciences [,] Malaise trap in open area elev 885 m, MA-02-11B-60/ HOLOTYPE ơ Cyamops mathisi Rung \& Ale-Rocha CAS [red]." The holotype is double mounted (right side glued on white paper triangle), is in very good condition (right outer fronto-orbital broken, left vertical seta and outer fronto-orbital missing, tarsi of mid right leg missing) and is deposited in the CAS. Paratypes ( 3 males, 3 females; CAS) bear the same label as the holotype.

Distribution. Madagascar, Province Fianarantsoa.

Etymology. The species epithet, mathisi, is to honor and recognize the contributions of Wayne N. Mathis to dipterology and to the study of Cyamops.

Remarks. Among the Afrotropical species, C. mathisi sp. nov. is most difficult to separate from $C$. freidgergi Baptista \& Mathis, 2000. Both species have two pairs of setae on the scutellum, the wing mostly hyaline, at most with light infuscation, and lack anepisternal setae on the dorsal right margin of the anepisternum. Males of both species can be easily separated based on the shape of the surstyli and sternite $6+7$. Females of C. freidbergii are unknown.
Cyamops nigeriensis Baptista \& Mathis, 2000

Cyamops nigeriensis Baptista \& Mathis, 2000: 487. Nigeria. NW State: Badeggi Rice Research Station. HT male USNM; Mathis \& Rung 2011: 362 [World catalog].

Specimens examined. IVORY COAST. Bouaké, December 1980 (pan trap), P. Cochereau (6 males, 12 females; CSCA).

Distribution. Afrotropical: Ivory Coast, Nigeria, Namibia. Remarks. This species was previously only known from Nigeria and Namibia, and its discovery in the Ivory Coast extends our knowledge of this species' distribution.

\section{Neotropical species}

With the inclusion of the new species described below, a total of 11 species of Cyamops are known in the New World. Of these, eight occur in the Neotropical Region. Females of all Neotropical species that have had their abdomens dissected (four species total) have four spermathecae. This number contrasts with the two/three spermathecae found in species from other regions and is a putative synapomorphy for the Neotropical fauna.

\section{Key to New World species of Cyamops}

1. Anepisternum bare along posterior margin (Figs 6 and 7) 2

1 '. Anepisternum setose along posterior margin, usually bearing 1 seta and a few setulae (Baptista \& Mathis 1994: 23, fig. 55)

\section{6}

2. Only apical scutellar seta present (United States) C. imitatus Sturtevant

2'. Apical and basal scutellar setae present (Fig. 8) ................ 3

3. Wing hyaline (BAPTISTA \& MATHIS 1994: 15, fig. 22) (Canada, USA) C. halteratus Sabrosky

3'. Wing at least partially infuscate..... 4

4. Vein $\mathrm{R}_{2+3}$ sinuous (BAPTISTA \& Mathis 1994: 15, fig. 24); midand hind tibiae mostly yellow; scutellar disc slightly convex (eastern Canada and United States)

C. nebulosus Melander

$4^{\prime}$. Vein $\mathrm{R}_{2+3}$ straight or nearly so; mid- and hind tibiae lightly infuscate to brown; scutellar disc flat

5. Right surstylus as narrow as left; hypandrial projection large and exposed; $7^{\text {th }}$ and $8^{\text {th }}$ sternites reduced (BAPTISTA $\&$ MATHIS 1994: 20, fig. 43) (Brazil: São Paulo)

C. fasciatus Baptista \& Mathis

5'. Right surstylus much broader than left; hypandrial projection of normal length, not large, usually hidden beneath right surstylus; $7^{\text {th }}$ and $8^{\text {th }}$ sternites well developed, fused to $5^{\text {th }}$ sternite (Baptista \& Mathis 1994: 18, figs 37-39) (Mexico: Chiapas) C. buenorum Baptista \& Mathis

6 . Face of male and female angulate in profile, sloped anteroventrally from base of antenna to vibrissal angle; facial carina lacking in male; frons of male entirely depressed below insertion of fronto-orbital setae; eye densely micro- 
setulose (Colombia)

C. colombianus Baptista \& Mathis

6 '. Face of maleand female shallowly and vertically arched, never angulate; facial carina present in male; frons of male depressed only medially; eye microsetulae sparse, difficult to discern (Fig. 4)

7. Wing cell $\mathrm{R}_{4+5}$ usually completely infuscate, dividing subapical white spot (Fig. 13) (pale specimens with only traces of brown on the veins around cell $\mathrm{R}_{4+5}$ ); mid and hind femora mostly yellow ..... ... 8

7'. Wing cell $\mathrm{R}_{4+5}$ with a conspicuous, undivided subapical white spot; mid and hind femora mostly dark 12

8. Basal 3-4 rays of arista bifurcate; hind tibia completely yellow; postpronotum shiny, lacking microtomentum (Costa Rica, Honduras, Mexico: Chiapas) C. americus Baptista \& Mathis

8'. Basal rays of arista not bifurcate; middle portion of hind tibia darkened to completely yellow; postpronotum shiny to subshiny, microtomentose

9

9. Right surstylus approximately trapezoidal on apical $3 / 4$, margins tapering toward apex, with a narrow, setose, transversal, preapical stripe (BAPтISTA \& Mathis 2000: 484, fig. 1) (Guyana) C. funkae Baptista \& Mathis

$9^{\prime}$. Right surstylus not as above ..... 10

10. Hind femur infuscate on apical $1 / 6$; produced portion of male face generally $3 / 4$ width of $1^{\text {st }}$ flagellomere; surstyli not as below 11

$10^{\prime}$. Hind femur infuscate on apical $1 / 2$; face of male only slightly produced, produced portion of face $1 / 4$ width of $1^{\text {st }}$ flagellomere; right surstylus, from ventral view, approximately pear-shaped, narrower at base, and with an apical "notch" (Baptista \& Mathis 2000: 486, fig. 7) (Panama) .... Cyamops sp. 2 (Baptista \& Mathis 2000)

11. Surstyli very elongate, apical portion concealed below $6^{\text {th }}$ $7^{\text {th }}$ sternite; right surstylus boot-shaped, longer than left surstylus; left surstylus not bifurcated apically (BAPTISTA \& Mathis 2000: 486, fig. 5) (Trinidad)

Cyamops sp. 1 (BAPTISTA \& MathIS 2000)

11 '. Surstyli not very elongate, apex of right surstylus only partially concealed below sternites 6-7; right surstylus, in ventral view, with a centrally elevated area bearing setae, and right lower corner bearing a setose protuberance; left surstylus clearly bifurcating apically in lateral view (Figs 14 and 15) (Brazil: Amazonas, Maranhão)

C. manauensis sp. nov.

12. Right surstylus with apical margin deeply concave in middle, having a hook-shaped appearance; aedeagal apodeme length equal to length of combined $6^{\text {th }}$ and pregenital tergites (BAтTIsta \& Mathis 1996: 246, fig. 1) (Brazil: Rio de Janeiro) C. sabroskyi Baptista \& Mathis
12 '. Right surstylus with apical margin convoluted, irregular (BAPTISTA \& MATHIS 1994: 24, fig. 58); aedeagal apodeme very large, length equal to combined length of $5^{\text {th }}, 6^{\text {th }}$, and pregenital tergites (Brazil: São Paulo, Costa Rica, Peru)

C. neotropicus Hennig

Remarks. In the key above, the two species referred to as "1" and " 2 ", from Trinidad and Panama, respectively, were not named by BAPTISTA \& MATHIS (2000) because the specimens available were few and in their condition precluded a thorough description. We have kept these species in this revised "Key to New World species of Cyamops" in the hope that further collecting in those countries will produce more specimens, and that one day they can be described and have their names in the appropriate couplets.

\section{Cyamops manauensis sp. nov.}

Figs $11-18$

Description. Male (two specimens measured): Adult length 2.2-2.4 mm; wing length 1.9-2.2 $\mathrm{mm}$; wing width 0.6-0.7 $\mathrm{mm}$. Head (Figs 11 and 12): Ocellar tubercle mostly polished, shiny spot on vertex reaching $2 / 3$ distance to eye margin; frons subshiny microtomentose, velvet at deepest portion, parafacial margins densely microtomentose, silver up to just below insertion of fronto-orbital setae; antenna mostly yellow, slightly infuscate at dorsal margin of pedicel; face constricted medially by the anteroventral margin of the eyes, expanded into a ventral triangular region below level of pseudovibrissae and bearing a vertical, midfacial, brownish carina, facial triangle brown; gena yellow, when viewed anteriorly conspicuously silvery white microtomentose; palpus and labellum mostly pale yellow; face in profile shallowly and vertically arched, not angulate; eye sparsely microsetulose. Chaetotaxy: Inner fronto-orbital setae slightly divergent; arista with about 10-11: 3 rays, none bifurcate; peristomal setae 8-10. Thorax: Mostly brown. Postpronotum subshiny microtomentose; halter mostly white, infuscate at base; mesonotum slightly longer than wide; scutellum trapezoidal, disc flattened. Chaetotaxy: Dorsocentral setae $0+1$, subequal in length to the $1^{\text {st }}$ scutellar seta; many setulae between dorsocentral and acrostichal rows in most specimens; setulae of mesonotum at most $1 / 3$ length of dorsocentral seta; scutellar setae 2 pairs, basal pair about $2 / 3$ length of apical; anepisternum bearing posterior setae on upper 1/3. Legs: Mostly yellow; fore femur brown infuscate dorsally in the holotype; hind femur brown apically; apical and sometimes subapical tarsomere of each leg brown; spine-like setulae on fore femur 10. Wing (Fig. 13): Partially hyaline, mostly with dark pattern; cell $\mathrm{r}_{4+5}$ entirely infuscate, dividing subapical white spot; brown area near apex of vein $\mathrm{R}_{1 ;}$ costal vein ratio I: 1-1.4; costal vein ratio II: 3.7-4.5; wing ratio 2.7-2.9. Abdomen (Figs 14-17): Coloration as described for the thorax, without polished segments; tergites 6 and 7 large, subequal in length; posterior process of sternites 6 and 7 as in Fig. 14. Male terminalia as follows: Left surstylus narrow, elongate, approxi- 

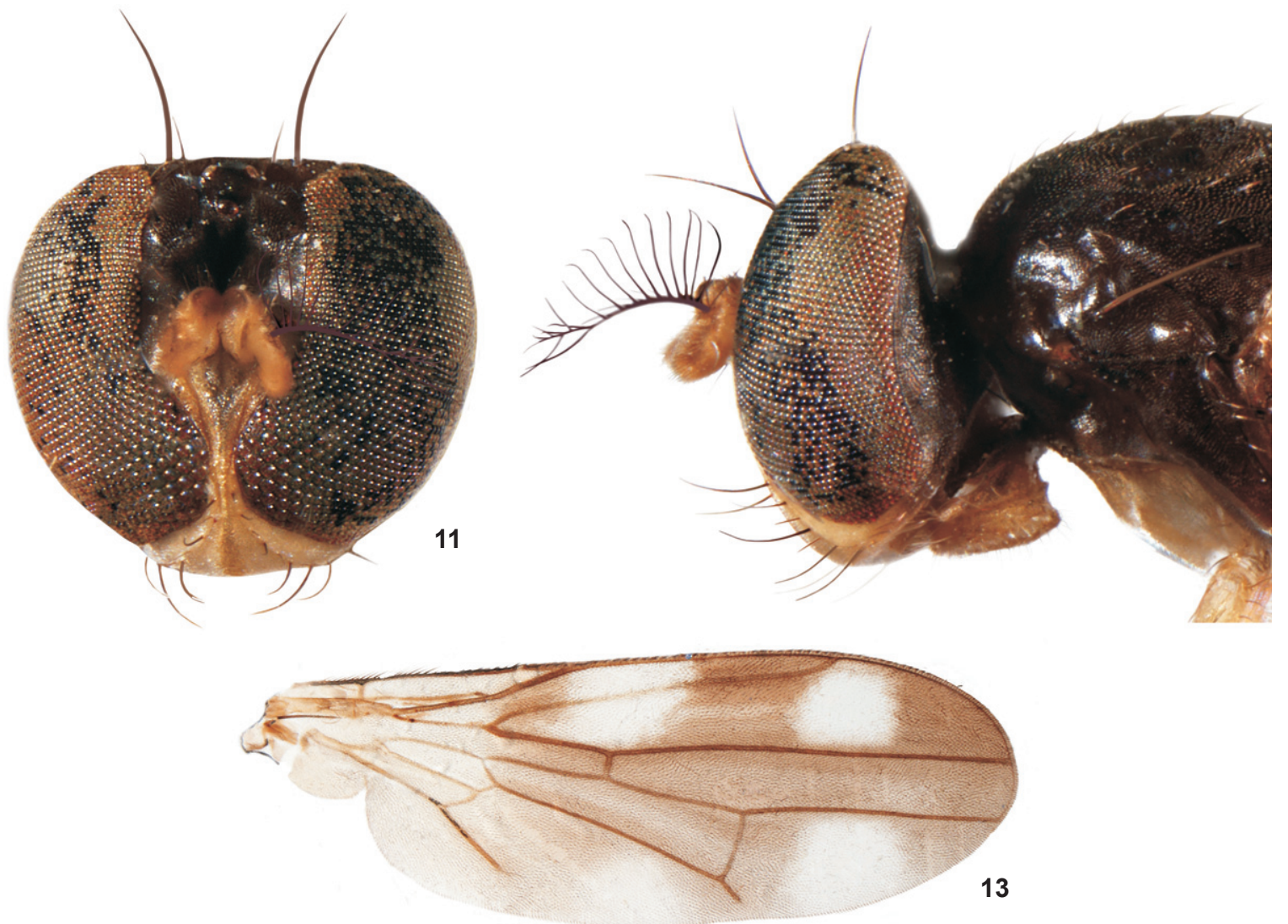

Figures 11-13. Photographs of Cyamops manauensis sp. nov., male paratype: (11) head, frontal view; (12) head and anterior portion of thorax, lateral view; (13) wing, dorsal view. Not all to the same scale.

mately boot-shaped in ventral view; right surstylus slightly shorter but considerably wider than left, in ventral view subrectangular, central region with a lump bearing setae and right lower corner bearing a setose protuberance; hypandrium and gonopods asymmetrical, left gonopod digitiform, bearing small setulae; ejaculatory apodeme lost during specimen preparation; postero-ventral portion of aedeagal apodeme fused with hypandrium.

Female (two specimens measured): Adult length 2.6-2.7 $\mathrm{mm}$; wing length 2.5-2.8 mm; wing width 0.9-1 mm. Head: Ocellar tubercle polished and shiny spot on vertex more extensive. Antenna with dorsal $1 / 2$ and apex of $1^{\text {st }}$ flagellomere brown; face mostly dark brown, not constricted medially by the eyes, bearing a more elevated, parallel, central region (a broad carina); facial carina mostly polished, encroached by lateral microtomentum basally; gena and lateral portions of face below level of pseudovibrissa strongly microtomentose; palpus brown; face in profile angulate, sloped anteroventrally from base of antenna to vibrissal angle, thereafter slightly receded to oral margin; arista with 13-14 dorsal rays. Thorax: Dorsocentral setulae typically better developed than in the males. Abdomen (Fig. 18): Demarcation between tergites 7 and 8 sharp dorsally; sternite 8 fused to $7^{\text {th }} ; 4$ spermathecae present, oblong, one pair slightly smaller than other, apical portion of spermathecal ducts sclerotized.

Type material: The holotype male is labeled "BRA[SIL]. Amazonas[,] Manaus, Res[erva] Ducke[,] Igarapé Barro Branco[,] Armadilha Malaise/12- 222004 IX [day and month handwritten] Henriques A. Leg/HOLOTYPE ơ Cyamops manauensis Rung \& Ale-Rocha INPA [red]." The holotype is double mounted (right side glued on white paper triangle), is in fair condition (right eye collapsed, right wing partly broken, left hind leg with only basal tarsomere present, remaining tarsomeres missing, left dorsocentral and katepisternal setae lost, abdomen dissected and attached to a microvial] and is deposited in INPA. Paratypes (4 females; INPA) are from the same country and state as the holotype. All of them were collected with Malaise trap and bear the following additional information: Manaus, Carauari, July 2005, A. Henriques et al. (1 female); Parque Nacional do Jaú, Rio Papagaio, 01 June 2003, J.A. Rafael \& J. Vidal (1 female), Rio Jaú, Joca, 27 April- 03 May 1995, J.A. Rafael \& J. Vidal (1 female), Seringal, 27 April- 03 May 1995, J.A. Rafael \& J. Vidal (1 female). 

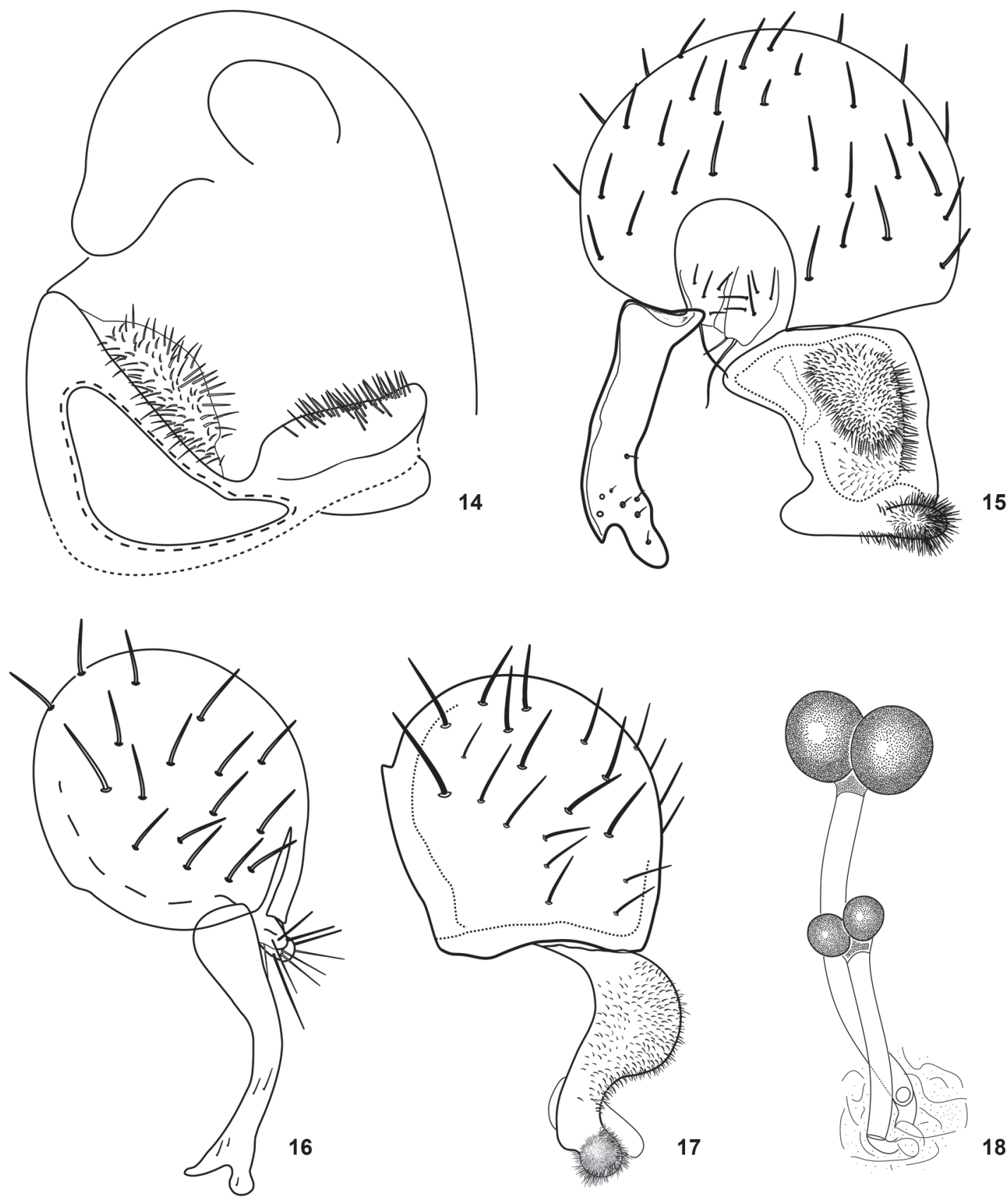

Figures 14-17. Illustrations of Cyamops manauensis sp. nov. (14-16) Male terminalia (paratype): (14) sternite 6+7, ventral view; (15) epandrium and surstyli, ventral view; (16) epandrium and surstylus, left side, lateral view; (17) epandrium and surstylus, right side, lateral view. (18) Spermathecae, paratype. Spermathecae not to the same scale as male terminalia.

Other specimens examined. Maranhão. Caxias, Fazenda Frexeira, 28 July - 01 Aug 2001, F. Limeira-de-Oliveira (1 male; CZMA); Caxias, Reserva Ecológica Inhamum, 02-08 Nov 2005, G.A. Cunha (2 females; CZMA).

Distribution. Brazil: Amazonas and Maranhão.
Etymology. The species epithet, manauensis, refers to the type locality of the species, Manaus.

Remarks: A total of three species have been previously recorded from Brazil, all from southern states: $C$. fasciatus and C. neotropicus (state of São Paulo), and C. sabroskyi (state of Rio 
de Janeiro). Among Neotropical species of Cyamops, C. americus, C. funkae, and C. manauensis sp. nov., in addition to two undescribed species mentioned in BAPTISTA \& MATHIS (2000), are difficult to separate based on external characters. They all share a similar wing pattern (with cell $r_{4+5}$ completely infuscate dividing subapical white spot) and coloration of the legs. For this reason, dissection of the male terminalia is essential to differentiate each of them.

\section{ACKNOWLEDGMENTS}

We thank Augusto L. Henriques (INPA) and Francisco L. de Oliveira (CZMA) for the loan of the material, and Stephen Gaimari (CSCA) for facilitating access to specimens. Tom Manos assisted with the scanning electron microscopy. Collecting was financed by a grant from CNPq (Conselho Nacional de Desenvolvimento Científico e Tecnológico, process \# 574999/2008-6).

\section{LITERATURE CITED}

Baptista, A.R.P. \& W.N. Mathis. 1994. A revision of New World Cyamops Melander (Diptera: Periscelididae). Smithsonian Contributions to Zoology 563: 1-25.

Baptista, A.R.P. \& W.N. Mathis. 1996. A new species of Cyamops Melander (Diptera: Periscelididae) from Brazil, with distributional notes on another species. Proceedings of the Entomological Society of Washington 98: 245-248.

Baptista, A.R.P. \& W.N. Mathis. 2000. Notes on the genus Cyamops Melander (Diptera: Periscelididae), including description of ten new species. Proceedings of the Entomological Society of Washington 102: 481-506.

Grimaldi, D.A. 2009. The Asteioinea of Fiji (Insecta: Diptera: Periscelididae, Asteiidae, Xenasteiidae). American Museum Novitates 3671: 1-59.

Hennig, W. 1958. Die Familien der Diptera Schizophora und ihre phylogenetischen Verwandtschaftsbeziehungen. Beiträge zur Entomologie 8 (5/6): 505-688.

HenNig, W. 1969. Newe Gattungen und Arten der Acalyptratae. Canadian Entomologist 101 (6): 589-633.

Kноo, K.C. 1985. The Australian species of Cyamops Melander (Diptera: Periscelididae). Australian Journal of Zoology 32: 527-536.
Khoo, K.C. \& C.W. Sabrosky. 1989. 75. Family Stenomicridae, p. 551. In: N.L. Evenhuis (Ed.). Catalog of the Diptera of the Australasian and Oceanian Regions. Honolulu, E.J. Brill and B.P. Bishop Museum special publication 86, 1155p.

Mathis, W.N. \& A. Rung. 2011. World catalog and conspectus on the family Periscelididae (Diptera: Schizophora), p. 341377. In: I. BRAKe \& F.C. Thompson (Eds). Contributions to the Systema Dipterorum (Insecta: Diptera). WashingtonSofia-Moscow, Myia 12, viii+564 p.

Mathis, W.N. \& M. Sueyoshi. 2011. New species of the genus Cyamops Melander from New Zealand (Diptera, Periscelididae, Stenomicrinae). ZooKeys 114: 29-40.

McAlpine, J.F. 1981. Morphology and terminology-adults, p. 963. In: J.F. McAlpine; B.V. Peterson; G.E. Shewell; H.J. Teskey; J.R. VoCKeroth \& D.M. WoOd (Eds). Manual of Nearctic Diptera. Ottawa, Agriculture Canada, Research Branch, Monograph 27, vol. 1, VII + 674 p.

Melander, A.L. 1913. A synopsis of the dipterous groups Agromyzinae, Milichiinae, Ochthiphilinae and Geomyzinae. Journal of the New York Entomological Society 21: 283300.

Poole, R.W. \& P. Gentili. 1996. Nomina Insecta Nearctica. A check list of the insects of North America. Rockville, Entomological Information Services, vol. 3, 1143p.

Rafael, J.A. \& I.N. Gorayeb. 1982. Tabanidae (Diptera) da Amazônia, I - Uma nova armadilha suspensa e primeiros registros de mutucas de copas de árvores. Acta Amazonica 12 (1): 232-236.

Sabrosky, C.W. 1958. New species and notes on North American acalyptrate Diptera. Entomological News 69: 169-176.

Sabrosky, C.W. 1965. Family Anthomyzidae, p. 810-820. In: A. Stone; C.W. Sabrosky; W.W. Wirth; R.H. Foote \& J.R. Coulson (Eds). A catalog of the Diptera of America north of Mexico. Washington, D.C., USDA, handbook 276, IV + 1696p.

Sturtevant, A.H. 1954. Nearctic flies of the family Periscelidae (Diptera) and certain Anthomyzidae referred to the family. Proceedings of the United States National Museum 103 (3332): 551-561.

Sueyoshi, M. \& W.N. Mathis. 2004. A new species of Cyamops Melander, 1913 (Diptera: Periscelididae) from Japan and a review of the Japanese Periscelididae. Proceedings of the Entomological Society of Washington 106: 74-84.

Submitted: 16.IX.2011; Accepted: 27.X.2011

Editorial responsibility: Gabriel L.F. Mejdalani 


\section{Errata for ZOOLOGIA volume 28(6)}

Volume $28(6)$, page 803 , title:

Reads: Periscelidae

Should read: Periscelididae

All changes are already incorporated in the online version of these articles available at http://www.scielo.br/zool 